\title{
Is the short term limit value for sulphur dioxide exposure safe? Effects of controlled chamber exposure investigated with bronchoalveolar lavage
}

\author{
T SANDSTROัM, ${ }^{1}$ N STJERNBERG,${ }^{2}$ M-C ANDERSSON,${ }^{2}$ \\ B KOLMODIN-HEDMAN, ${ }^{2}$ R LUNDGREN, ${ }^{1}$ T ÅNGSTRÖM ${ }^{3}$
}

From the Department of Lung Medicine, University Hospital, National Board of Occupational Safety, ${ }^{2}$ Medicalo Division, and Department of Cytology, ${ }^{3}$ University Hospital, Umeå, Sweden

ABSTRACT Bronchoalveolar lavage (BAL) which has not previously been used in investigating the $e^{\omega}$ effect of sulphur dioxide $\left(\mathrm{SO}_{2}\right)$ on the human lung was performed on 12 subjects before and aftero controlled chamber exposure with $\mathrm{SO}_{2}$ for 20 minutes. BAL fluid 24 hours after exposure with 10 mgo $\mathrm{SO}_{2} / \mathrm{m}^{3}$ (4 ppm, 10 subjects) showed increased alveolar macrophage activity as judged by an increase in lysozyme positive macrophages. Twenty four hours after $20 \mathrm{mg} / \mathrm{m}^{3}$ (4 subjects) a further increasez was seen, which was accompanied by an increase in total numbers of macrophages and lymphocytes $\frac{0}{\tilde{\sigma}}$ Seventy two hours after exposure (4 subjects) cell numbers had virtually returned to pre-exposure ${ }_{-}^{-}$ levels. These previously uninvestigated reactions indicate potentially noxious effects of $\mathrm{SO}_{2}$ in the lungs at exposure levels that are regarded as relatively safe.

Sulphur dioxide $\left(\mathrm{SO}_{2}\right)$ is a gas that is rapidly oxidised to sulphuric acid in contact with moist epithelial surfaces in the eyes, nasopharynx, and lower airways, where it may cause damage. It is a major air pollutant in urban areas, particularly in the working environment of pulp industries and factories using various combustion and smelting processes. High peak exposures, many times exceeding the Swedish short term exposure limit of $13 \mathrm{mg} \mathrm{SO} / \mathrm{m}^{3}$ air $(5 \mathrm{ppm})$, have been frequently found ${ }^{1}$ (and $\mathrm{N}$ Stjernberg $e t$ al, unpublished data). Similar findings have been reported in other countries. ${ }^{23}$

Pulmonary effects of $\mathrm{SO}_{2}$ in man have mainly been studied indirectly by lung function tests, ${ }^{45}$ tests of hyperreactivity, ${ }^{6}$ and in epidemiological surveys ${ }^{17}$ (and N Stjernberg et al). Direct investigation has been restricted to workers who have died of massive exposure to $\mathrm{SO}_{2}$, in whom gross histopathological changes in the lung tissue with haemorrhagic alveolar oedema have been reported. ${ }^{8}$ Bronchoalveolar lavage (BAL), which is a commonly used method for investigating conditions at the alveolar level has not to our knowledge previously been used for studying $\mathrm{SO}_{2}$ effects in man.

Our aim, using the BAL technique, was to determine if short term exposure to $\mathrm{SO}_{2}$ in concentrations around the Swedish short term exposure limit, concen-

Accepted 15 February 1988 trations which are commonly found in industriak environment, causes potentially harmful effects on theo alveolar cell population.

\section{Subjects and methods}

\section{SUBJECTS}

Twelve healthy, non-smoking subjects, aged 22-305. (mean 24) participated in this investigation. None haळ a history of airway infection for at least six weeks before BAL or a history of bronchial hyperresponsive -5 ness. Pre-exposure lung function and gas distribution were normal in all subjects.

\section{SULPHUR DIOXIDE EXPOSURE}

The exposure chamber measured $3.20 \times 2.00 \times \frac{\text { ? }}{3}$ $2.20 \mathrm{~m}$ with an air volume of $14.1 \mathrm{~m}^{3}$. It was built of anodised aluminium with windows in one wall Ambient air was drawn continuously through thes chamber at $400 \mathrm{~m}^{3} / \mathrm{h}$, resulting in one air exchange about every two minutes. Pre-exposure measurement have shown low levels of particulate matter in the $e^{\omega}$ chamber. During exposure, the chamber air tem $<$ perature was kept at $20^{\circ} \mathrm{C}$ and the relative humidite around $50 \%$. The concentration of $\mathrm{SO}_{2}$ in the exposure chamber was controlled by adding a gas stream from a $1 \% \mathrm{SO}_{2}$ gas tube to the chamber aif inlet. The chamber air was continuously analysed with an electrochemical method in which $\mathrm{SO}_{2}$ is oxidised tof 
sulphate and the current registered on a recorder."

The subjects were exposed to 10 and $20 \mathrm{mg} \mathrm{SO} / \mathrm{m}^{3}$ air (4 and $8 \mathrm{ppm}$ respectively). The exposure time was 20 minutes and the test subjects were working on a bicycle ergometer with a work load of $75 \mathrm{~W}$. Immediately before and after exposure, and 15 minutes after exposure, dynamic spirometry was recorded using a Vitalograph spirometer. Dynamic spirometry was also performed before the postexposure BAL. Before, during, and at the end of the exposure, the test subject was asked about symptoms using a standardised questionnaire.

\section{BA L}

The method of BAL is slightly modified from previous studies by our group. ${ }^{10}$ (All bronchoscopies were performed by the same investigator.) A flexible fibreoptic bronchoscope, Olympus BF $1 \mathrm{~T}$ or BF 1T10, was used with the subject in the supine position. The same instrument was used for all examinations in each subject. Lidocain was used for topical anaesthesia. Atropine 0.5-0.75 mg was given subcutaneously as premedication. The bronchoscope was inserted through the mouth and wedged in the middle lobe bronchus. Sterile phosphate buffered saline (PBS-A) at $37^{\circ}, \mathrm{pH} 7 \cdot 3$, was infused in four aliquots of $60 \mathrm{ml}$ and gently suctioned back after each infusion into a siliconised container placed in ice water. The chilled lavage fluid was filtered through a nylon filter (pore diameter $100 \mu \mathrm{m}$, Syntab Product AB, Malmö, Sweden) at the laboratory and centrifuged at $400 \mathrm{G}$ for 15 minutes. The cell pellet was resuspended in balanced salt solution to give a concentration of $10^{6}$ cells per $\mathrm{ml}$. The total number of cells in the lavage fluid was counted in a Bürker chamber.

Cytocentrifugal smears were prepared with $5 \times 10^{4}$ non-epithelial cells per slide using a Cytospin 2 (Shandon Southern Instruments Inc, Sewickly, PA, USA). Slides were stained according to May-Grün-
wald-Giemsa for standard cell differential counts and two hundred cells per slide were counted. Mast cells were counted on slides stained with acid toluidine blue and counterstained with Mayer's acid haematoxylin. ${ }^{\text {. }}$ Lysozyme positive macrophages were shown with lysozyme antibody using an immunoperoxidase technique (Dakopatts A/S, Copenhagen, Denmark). The ratio helper-inducer/suppressor-cytotoxic $T$ cells was determined using the Simultest T Helper/Suppressor Test (Becton Dickinsson AB, Stockholm, Sweden).

BAL was performed at least two weeks before exposure to $\mathrm{SO}_{2}$ in all 12 subjects (table). Ten subjects underwent BAL 24 hours after exposure with $10 \mathrm{mg}$ $\mathrm{SO}_{2} / \mathrm{m}^{3}$. BAL was also performed in four subjects 24 hours after exposure with $20 \mathrm{mg} \mathrm{SO} / \mathrm{m}^{3}$ and on four subjects 72 hours after exposure. The time between exposures to $\mathrm{SO}_{2}$ varied between three and five months in the individuals who were exposed twice. Informed consent was obtained from the subjects and the study was approved by the ethical committee of the University of Umeå.

\section{STATISTICS}

Wilcoxon's non-parametric signed rank test was used.

\section{Results}

\section{BRONCHOSCOPY}

Before exposure and after $10 \mathrm{mg} \mathrm{SO} / \mathrm{m}^{3}$, all subjects had normal endobronchial findings. Twenty four hours after exposure to $20 \mathrm{mg} \mathrm{SO} / \mathrm{m}^{3}$, all four subjects showed a mucosal erythaema in the distal part of trachea and proximal main bronchi.

BAL

The median amount of BAL fluid recovered at the preexposure lavage was $69 \%$ (interquartile range 64 $72 \%$ ) and did not differ significantly after exposure. The number of neutrophils, eosinophils, and mast

Cell numbers in bronchoalveolar lavage fluid after controlled exposure to sulphur dioxide. Data are given as median with range

\begin{tabular}{|c|c|c|c|c|c|c|c|}
\hline & \multirow{2}{*}{$\begin{array}{l}\text { Total } \\
\text { cell count } \\
\times 10^{7} / l\end{array}$} & \multicolumn{2}{|c|}{ Lymphocytes } & \multicolumn{2}{|c|}{ Macrophages/monocytes } & \multicolumn{2}{|c|}{$\begin{array}{l}\text { Lysozyme positive } \\
\text { macrophages/monocytes }\end{array}$} \\
\hline & & $\times 10^{7} / l$ & $\%$ & $\times 10^{7} / l$ & $\%$ & $\times 10^{7} / l$ & $\%$ of macrophages \\
\hline $\begin{array}{l}\text { Before exposure } \\
(n=12)\end{array}$ & $\begin{array}{l}6 \cdot 9 \\
(2-17 \cdot 4)\end{array}$ & $\begin{array}{l}0 \cdot 3 \\
(0 \cdot 1-2 \cdot 6)\end{array}$ & $\begin{array}{l}6 \\
(2-18)\end{array}$ & $\begin{array}{l}6 \cdot 3 \\
(11 \cdot 8-14 \cdot 3)\end{array}$ & $\begin{array}{l}92 \\
(81-97)\end{array}$ & $\begin{array}{l}0.4 \\
(0 \cdot 1-3 \cdot 4)\end{array}$ & $\stackrel{5}{(3-20)}$ \\
\hline $\begin{array}{l}24 \mathrm{~h} \text { after } 10 \mathrm{mg} \\
\mathrm{SO}_{2} / \mathrm{m}^{3} \\
(\mathrm{n}=10)\end{array}$ & $\begin{array}{l}6 \cdot 0 \\
(1 \cdot 4-14 \cdot 0)\end{array}$ & $\begin{array}{l}0 \cdot 5 \\
(0 \cdot 1-1 \cdot 3)\end{array}$ & $\begin{array}{l}7 \\
(4-22)\end{array}$ & $\begin{array}{l}4 \cdot 9 \\
(1 \cdot 3-12 \cdot 3)\end{array}$ & $\begin{array}{l}91 \\
(75-93)\end{array}$ & $\begin{array}{l}0 \cdot 8 \\
(0 \cdot 1-1 \cdot 5)\end{array}$ & $\begin{array}{l}14 \\
(5-19)\end{array}$ \\
\hline $\begin{array}{l}24 \mathrm{~h} \text { after } 20 \mathrm{mg} \\
\mathrm{SO}_{2} / \mathrm{m}^{3} \\
(\mathrm{n}=4)\end{array}$ & $\begin{array}{l}16 \cdot 0 \\
(8 \cdot 6-21 \cdot 0)\end{array}$ & $\begin{array}{l}3 \cdot 1 \\
(1 \cdot 2-5 \cdot 9)\end{array}$ & $\begin{array}{l}20 \\
(12-28)\end{array}$ & $\begin{array}{l}12 \cdot 4 \\
(6 \cdot 8-14 \cdot 3)\end{array}$ & $\begin{array}{l}76 \\
(68-84)\end{array}$ & $\begin{array}{l}2 \cdot 6 \\
(i \cdot 5-4 \cdot 6)\end{array}$ & $\begin{array}{l}18 \\
(15-22)\end{array}$ \\
\hline $\begin{array}{l}72 \mathrm{~h} \text { after } 20 \mathrm{mg} \\
\mathrm{SO}_{2} / \mathrm{m}^{3} \\
(\mathrm{n}=4)\end{array}$ & $\begin{array}{l}8 \cdot 2 \\
(7 \cdot 0-12 \cdot 2)\end{array}$ & $\begin{array}{l}1 \cdot 0 \\
(0 \cdot 5-1 \cdot 5)\end{array}$ & $\begin{array}{l}12 \\
(6-20)\end{array}$ & $\begin{array}{l}7 \cdot 1 \\
(5 \cdot 8-11 \cdot 2)\end{array}$ & $\begin{array}{l}88 \\
(79-92)\end{array}$ & $\begin{array}{l}0.5 \\
(0 \cdot 4-2 \cdot 1)\end{array}$ & $\begin{array}{c}7 \\
(4-17)\end{array}$ \\
\hline
\end{tabular}


cells, and the ratio of helper-inducer/suppressorcytotoxic $T$ cells, were within normal limits and were not significantly changed after exposure. The counts for lymphocytes and macrophages/monocytes are given in the table.

Twenty four hours after exposure to $10 \mathrm{mg} \mathrm{SO} / \mathrm{m}^{3}$ there was a significant increase in lysozyme positive alveolar macrophages ( $\mathrm{Lys}^{+} \mathrm{MF}$ ) in total number and in per cent of the total amount of alveolar macrophages (Tot-MF) compared with values before exposure ( $\mathrm{p}<0.01$ respectively).

Twenty four hours after exposure to $20 \mathrm{mg} \mathrm{SO} / \mathrm{m}^{3}$ $\mathrm{Lys}^{+} \mathrm{MF}$ were further increased, both in per cent of Tot-MF and in total number. Tot-MF and the total cell number were also increased. A mild lymphocytosis was also seen, with a median value of $20 \%$ (range 12 $28 \%$ ) as compared with $6 \%$ (range $2-18 \%$ ) before exposure. The total number of lymphocytes in BAL was two to four times higher than before exposure. An increase in the numbers of macrophages and lymphocytes was found in all four subjects.

Seventy two hours after exposure to $20 \mathrm{mg} \mathrm{SO} / \mathrm{m}^{3}$ lymphocytes, Lys ${ }^{+} \mathrm{MF}$, Tot-MF, and total cell numbers had virtually returned to pre-exposure levels.

\section{LUNG FUNCTION}

Vitalograph recordings before, immediately after, and 15 minutes after exposure to $\mathrm{SO}_{2}$ showed no significant decrease in lung function. Similar results were obtained 24 and 72 hours after exposures immediately before BAL.

\section{SYMPTOMS}

The subjects reported mild symptoms from the eyes and nose during exposure. All denied symptoms from the eyes or airways after exposure.

\section{Discussion}

Sulphur dioxide is a common environmental pollutant ${ }^{3}$ and large numbers of factory workers world wide are frequently exposed to levels well exceeding the short term exposure limits, which vary between 10 and $20 \mathrm{mg} \mathrm{SO} / \mathrm{m}^{3}$ in the industrialised countries. ${ }^{2}$ Until now, the effects of short term exposure of $\mathrm{SO}_{2}$ on the human lung have not been investigated by a direct technique such as BAL.

The $\mathrm{SO}_{2}$ exposure levels in the present study are based on previous measurements in pulp industry works and are equal to the upper and lower range of short term exposure limits in industrialised countries $^{112}$ (and N Stjernberg et al). The controlled chamber exposures were designed to simulate the work conditions in the type of industries in which exposure to $\mathrm{SO}_{2}$ is frequent and particulate levels low. The workers in these industries are mainly occupied with supervising chemical processes but are frequent 13 exposed to peak levels of $\mathrm{SO}_{2}$ during short periods. when they check and adjust the machinery. The workload is mainly light to moderately heavy which is why we chose $75 \mathrm{~W}$ on the ergometer bicycle. The workload also means that the workers are not forces to breathe much through the mouth.' This is beneficial, since the exposure of lower airways to $\mathrm{SO}_{2}$ is distinctly higher during oral breathing than during nasal breathing and rapidly increases with increase airflow. Approximately $98 \%$ of $\mathrm{SO}_{2}$ had been found to be absorbed in the nasopharynx during nasal breathe ing. ${ }^{1314}$ Even though the doses of $\mathrm{SO}_{2}$ that reach the alveoli appear to be small the cell reactions in BAID fluid indicate noxious effects at this level of the airways, by contrast with the mild symptoms fron $\$$ upper airways and absence of airflow obstruction. $\omega$

Lysozyme positivity is a property of monocytes newly recruited to the alveoli and is usually lost whem they have matured to macrophages. ${ }^{15}$ Lysozyme in macrophages is also believed to be a marker of celt activation and may be increased by a variety ow stimuli. ${ }^{1617}$ After the low exposure to $\mathrm{SO}_{2}, 10 \mathrm{mg} / \mathrm{m}^{3 \mathrm{~N}} \frac{\mathrm{T}}{\mathrm{T}}$ Tot-MF was unchanged while the relative numbers of $\mathrm{Lys}^{+} \mathrm{MF}$ were increased. This indicates that the Lyseo ${ }^{+}$MF seen in BAL had not migrated from the blood stream after the exposure but were residing alveolab macrophages who had reacted to the $\mathrm{SO}_{2}$ stimulus with lysozyme production. Twenty four hours after $2 \Phi$ $\mathrm{mg} \mathrm{SO} / \mathrm{m}^{3}$, however, a migration to the alveolo appears to have taken place. That that alveola $\bar{B}$ macrophage activation was the only observed cellula $\overrightarrow{5}$ reaction after the low exposure level may indicate tha $\bar{B}$ this is a prime target cell for $\mathrm{SO}_{2}$. Macrophages als $\bar{Y}$ have the ability to induce lymphocyte chemotaxis and proliferation by release of mediators such as Interleuken-1 and could thus induce the lymphocytosis

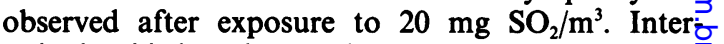
estingly, this lymphocytosis was not accompanied by any change in the ratio between Leu $2 /$ Leu 3 positive t $^{-}$ lymphocytes. This may indicate that the lympho 3 cytosis was mainly due to lymphocyte chemotaxis and not primarily to a proliferative response.

BAL after controlled chamber exposure witho gaseous pollutants seems to be a useful method for investigation of effects at the alveolar level of the lungo BAL, 24 hours after short term exposure with $10 \mathrm{mg}$ (40 $\mathrm{ppm})$ and $20 \mathrm{mg} \mathrm{SO} / \mathrm{m}^{3}(8 \mathrm{ppm})$, showed increased alveolar macrophage activity and at the higher dose $e_{-}^{\omega}$ also a mild lymphocytosis that had virtually returnes to normal 72 hours after exposure. These previouslyt uninvestigated reactions indicate potentially noxious effects of $\mathrm{SO}_{2}$ in the lungs at exposure levels that are presently regarded as relatively safe. Further studies are in progress to evaluate the effects of $\mathrm{SO}_{2}$ in theD lungs of man. 
This investigation was supported by grants from the National Association for Heart and Lung Patients and from the Norrlands Gas AB Fund.

\section{References}

1 Stjernberg N, Eklund A, Nyström L, Rosenhall L, Emmelin A, Strömqvist L-H. Prevalence of bronchial asthma and chronic bronchitis in a community in northern Sweden; relation to environmental and occupational exposure to sulphur dioxide. Eur J Respir Dis 1985;67:41-9.

2 Kolmodin-Hedman B, Swensson $\AA$. Nordiska expertgruppen för gränsvärdesdokumentation. 48. Svaveldioxid. Arbete och Hälsa 1984;18:1-63. (In Swedish.)

3 World Health Organisation. Sulphur oxides and suspended particulate matter. (Environmental health criteria 8.) Geneva: WHO, 1979.

4 Koenig JQ, Piersson WE, Horike M, Frank R. Effects of inhaled sulfur dioxide (SO2) on pulmonary function in healthy adolescents: exposure to $\mathrm{SO} 2$ alone or $\mathrm{SO} 2$ + sodium chloride droplet aerosol during rest and exercise. Arch Environ Health 1982;37:5-9.

5 Sheppard D, Wong WS, Uehara F, Nadel JA, Boushey HA. Lower threshold and greater bronchomotoric responsiveness of asthmatic subjects to sulphur dioxide. Am Rev Respir Dis 1980;122:873-8.

6 Utell MJ, Morrow PE, Hyde RW. Airway reactivity to sulfate and sulfuric acid aerosols in normal and asthmatic subjects. Journal of Air Pollution Control Association 1984;34:931-5.

7 Rom WN, Wood SD, White GL, Moon Bang K, Reading JC. Longitudinal evaluation of pulmonary function in copper smelter workers exposed to sulphur dioxide. Am Rev Respir Dis 1986;133:830-3.

8 Charan NB, Myers CG, Lakshminarayan S, Spencer TM. Pulmonary injuries associated with acute sulphur dioxide inhalation. Am Rev Respir Dis 1979;119:555-60.

9 Cedergren A, Wikby A, Bergner K. Comparison of high precision coulometric and West-Gaeke methods with the gravimetric method for preparation of standard sulphur dioxide gas blends using permeation tubes. Analytical Chemistry 1975;47:100-6.

10 Bjermer L, Engström-Laurent A, Lundgren R, Rosenhall L, Hällgren R. Hyaluronate and type III procollagen peptide concentrations in bronchoalveolar lavage fluid as a marker of disease activity in farmer's lung. Br Med J 1987;295:803-6.

11 Strobel S, Miller HRP, Ferguson A. Human intestinal mucosal cells: evaluation of fixation and staining techniques. $J$ Clin Pathol 1981;34:851-8.

12 Skalpe IO. Long term effects of sulphur dioxide exposure in pulp mills. Br J Ind Med 1964;21:69-73.

13 Brain J. The uptake of inhaled gases by the nose. Ann Otol Rhinol Laryngol 1970;79:529-40.

14 Frank NR, Yoder RE, Brain JD, Yokoyama E. SO2 (35S labeled) absorption by the nose and mouth under conditions of varying concentration and flow. Arch Environ Health 1969;18:315-22.

15 Bainton DF, Golde DW. Differentiation of macrophages from normal human marrow bone in liquid culture. J Clin Invest 1978;62:1555-69.

16 Cohn ZA, Wiener E. The particulate hydrolases of macrophages. I. Comparative enzymology, isolation and properties. $J$ Exp Med 1963;118:991-1008.

17 Leakes ES, Myrvik QN. Changes in the morphology and lysozyme content of free alveolar cells after intravenous injection of killed BCG in oil. Journal of the Reticuloendothelial Society 1968;5: 33-53. 